Portland State University

PDXScholar

Engineering and Technology Management

Faculty Publications and Presentations

Engineering and Technology Management

$10-8-2018$

\title{
Dynamics of Competition and Strategy: A Literature Review of Strategic Management Models and Frameworks
}

Mohammadsaleh Saadatmand

Portland State University

Maoloud Dabab

Portland State University

Charles Weber

Portland State University, webercm@pdx.edu

Follow this and additional works at: https://pdxscholar.library.pdx.edu/etm_fac

Part of the Engineering Commons

Let us know how access to this document benefits you.

\section{Citation Details}

M. Saadatmand, M. Dabab and C. Weber, "Dynamics of Competition and Strategy: A Literature Review of Strategic Management Models and Frameworks," 2018 Portland International Conference on Management of Engineering and Technology (PICMET), Honolulu, HI, 2018, pp. 1-14.

This Article is brought to you for free and open access. It has been accepted for inclusion in Engineering and Technology Management Faculty Publications and Presentations by an authorized administrator of PDXScholar. Please contact us if we can make this document more accessible: pdxscholar@pdx.edu. 


\title{
Dynamics of Competition and Strategy: A Literature Review of Strategic Management Models and Frameworks
}

\author{
Mohammadsaleh Saadatmand, Maoloud Dabab, Charles Weber \\ Dept. of Engineering and Technology Management, Portland State University, Portland, OR - USA
}

\begin{abstract}
This research reviews a comprehensive and somehow chronological literature in the models and frameworks of competition and strategy. Strategic management research is shaped around a core question that why some firms outperform others; several significant lines of work have emerged in the strategic management field since its infancy. These include industrial organization, the resource-based view and dynamic capabilities. Also, Competition essentially has been the focal point of scholars with diverse perspectives such as industrial economics and structural analysis, strategic groups, game theory, and competitive dynamics. In this research, we represent and summarize different perspectives of scholars in framing competition and strategy that is related to theory of the firm and differential firm performance; also, we show that there is a trend from static to dynamic frameworks of strategy and competition which have tried to find an answer to differential firm performance. Finally, we conclude by addressing the potential for utilizing new dynamic and systemic perspectives regarding theorizing dynamics of strategy and competition.
\end{abstract}

\section{INTRODUCTION}

The question "why do some companies exhibit persistent superior performance over others" for a long time has been of great importance to scholars and practitioners in the business. Hence, the field of strategic management is organized around this central question. 'This question does not assume that there will always be persistent performance differences between firms.' Rather, it supposedly assumes that in some situations persistent performance differences will arise between firms and those differences cannot be explained by traditional economic models of the firm. According to these traditional models, these differences should be unusual and if they exist, are most likely the result of anti-competitive collusive or monopolistic activities. [1] Also, 'although economic theory predicts that differences among rival firms will be eliminated over time by competition, empirical evidence in strategic management research has shown this is not to be the case'.[2] So, some frameworks and models from different views have been proposed over time by researchers for describing competition and such performance differences.

First models of competition based on the industrial organization (IO) economics were neo-classic models in a range from monopoly to perfect competition. Rooted in industrial organization (IO) economics and based on MasonBain approach, structure-conduct-performance (SCP) was proposed. SCP model states that a highly concentrated market structure, dominated by a few large firms, will give rise to little rivalry and excessive prices and profits. On the other hand, a structure consisting of many small firms will produce a high degree of rivalry and low prices and profits. The S-C-P model focuses on factors driving the intensity of rivalry; as such, this perspective has been very useful in understanding competition and competitive strategy.

The IO perspective and research tradition provide direct insights to how firms can obtain competitive advantage (in terms of IO, market power) through positioning in the industry structure and therefore pursuing strategies appropriate to that structure. However, the IO literature has limitations in producing a comprehensive theory of competitive advantage and differential firm performance. That theory is in the form of a mathematical model with an equilibrium solution which is an important constraint. Also, the IO literature focused on the industry as a unit of analysis and has suffered from a lack of attention to internal organizational factors and a general failure to measure conduct directly in empirical studies.

Whereas IO studies of the relationships between industry structure, conduct, and performance were intended to help develop public policies that promote competition, Michael Porter by taking a different point of reference pioneered the application of IO concepts to strategy formulation [1,2]. More specifically, he viewed the SCP paradigm as giving managers a systematic model for assessing competition and developing profit-maximizing strategies. So he proposed a well-known Five - Forces model for finding attractive industries and the ways of positioning in those industries for gaining superior performance. Indeed, he tried to answer two questions: where to compete? and how to compete? By disaggregating businessunit profits into components capturing industry effects, corporate effects and market share effects, Porter following [3] contend the importance of industry effects on firm performance. But, by extending Schmalensee 's approach, [4, $5,6]$ reveal that business effects were twice as important for company performance as effects of industry. These results stimulated research interest in the slightly refined question: "Why do firms in the same industry perform differently?" In answer, this question, several frameworks, and theories have been proposed. One problem with Porter's model and IO economics, in general, is that it tends to view industries as in equilibrium and competitive advantage as sustainable. However, in today's fast-paced world, resting on the achievements of yesterday's actions, even if they were successful, surely result in failure tomorrow. Today's 
competition needs dynamic actions, with perpetual updating and reevaluation of situation and strategy.

From an internal point of view, the dominant framework in the strategy literature to address the question has been resource-based view (RBV) of the firm. 'According to RBV, 'firms in the same industry perform differently because, even in equilibrium, firms differ in terms of resources and capabilities they control' $[7,8,9,10,11,12]$ These frameworks have one feature in common that is not suitable for fast-changing environment of today; they are all static and linear in nature. Hence, scholars started to propose more dynamic models and frameworks for strategy, competition, and subsequent differential firm performance. Strategy scholars have started to acknowledge explicitly the importance of dynamic processes, including the acquisition, development, and maintenance of differential bundles of resources and capabilities over time [9, $13,14,15,16,17,18]$. This perspective called dynamics capabilities is an extension of the RBV of the firm. One of the criticisms of the traditional resource-based view is that it largely ignores the external environment. Dynamic capabilities attempt to resolve this shortcoming: Teece [19] define dynamic capabilities as "the firm's ability to integrate, build, and reconfigure internal and external competencies to address rapidly changing environments." This definition brings into play both the resource-based view and the notion of rapidly changing environments.

Simultaneously, competitive dynamics that its root goes back to Austrian economics is another research stream which considered competition to be a dynamic market process rather than a static market condition. The concentration is on the process according which a market has moves toward or back from equilibrium; it is this movement and not the equilibrium, that was taken to be of interest. Competitive dynamics is the research area of interfirm competition according to special micro competitive acts and reactions, tactical and based on organizational contexts, and their forces and results. companies act and competitors have reactions, and these back and force determine existence and long-term performance. In contrast to Porter's approach that unit of analysis is industry level, this stream of research has focused on micro and real competitive actions and reactions among competing firms.

One more dynamic approach to dynamic competition has been evolutionary economics. Nelson and Winter [20] studied strategy, performance, and survival of companies over time using a variant of Darwin's natural selection theory. In the short-term, firms may pursue targets rather than profit maximization, such as "satisficing" or striving for profits to be achieved above some acceptable level. However, any firm veering too far will be weeded out of the marketplace eventually. Firms are cognizant of this harsh natural selection process and tend to learn over time how better to adapt.

These streams of strategy research show that strategy scholars are interested in dynamic theories that depict the dynamic evolution of performance differences among companies. making and experimenting theories that describe longitudinal performance differences patterns among companies would be an enormous step forward where mainstream strategy approaches have struggled. As Porter stated below: "while there has been considerable progress in developing frameworks that explain differing competitive success at any given point in time, our understanding of the dynamic processes by which firms perceive and ultimately attain superior market positions is far less developed" [21]. Ghemawat and Cassiman have pointed to the same problem as well. "The challenge of fully incorporating dynamics into how we think about strategy is a major one, perhaps the biggest one that the field faces going forward" [22].

In this research, by doing a literature review, we intend to show that models of competition in answering differential company performance in the field of strategic management have moved from static to more dynamic. From early days of research, strategic management has been a multidisciplinary field which has been borrowing heavily from economics, psychology, sociology, political science, evolutionary biology, systems science. But the main contribution originated from economics. In this paper, economics approaches as the main contributor are adopted as well. We would find how each individual study has examined competition and strategy. Also, we would represent what are commonalities in existing studies, what studies disagree about. We state that, because of the social and multidisciplinary nature of strategy, it is neccessary for scholars to adopt several perspectives described by different theories for the progression of this field.

\section{The HistoricAl OF SCHOLAR ThOUGHT}

\section{A. Two classic competition models: Cournot and Bertrand}

In 1838, Cournot proposed a model for competitive industries in which firms make decisions by acting rationally, trying to maximize profits, and strategically, taking into account its competitors' decisions at the time of making their own. In such model, economists assume that Industries are such that, due to entry barriers, there is little scope for new entrants to undermine the competitive structure of the industry. Therefore, by setting their output to maximize profits, the market will determine prices higher than the perfectly competitive equilibrium price, and under this condition firms will benefit in a sustained manner. Fifty years later Joseph Bertrand reviewed Cournot's work and proposed an extension to Cournot's model where, instead of firms setting the quantities, they adjust the price of the goods produced. Bertrand pointed out that there was a shortcoming in Cournot's argument: even though the solution holds in equilibrium, if one of the producers were to reduce their price by an infinitesimal amount, that producer would attract all buyers, which would then mean that the competitor would have to reduce their price to below the competitor's price, and so on leading to a 'price spiral' until the firms would be charging the cost of production. It is interesting that even though the Bertrand and Cournot competition models have very similar assumptions, they produce vastly different outcomes: in the Cournot model, firms make profits, whereas, in the Bertrand model, firms do not.

\section{B. Industrial organization (IO) perspective}

The traditional industrial organization paradigm is one of the foundations in strategic thinking and research. Let's take a 
look at earliest strategy frameworks and find their connections with IO. One of the earliest proposed frameworks in strategy field is Learned, Christensen, Andrews, and Guth (LCAG) framework that has become the foundation of business policy [36]. This framework defined strategy as a means of how a firm attempts to compete in its environment with considering important choices of different internal and external aspects of the business. It also took into account macro factors such political and social factors. Indeed LCAG suggested general and logical tests in determining firm's policies. In this framework, the successful firm was one that created and found a position in its industry which took into account internal and external factors. Since early business strategy literature after to LCAG was extensively translated fundamental paradigms of LCAG and extensions into a sequence of general analytical steps [37].

The essence of IO and subsequently proposed frameworks based on this paradigm (e.g., Bain/Mason) is that a company's performance in the market depends on the structural characteristics of the industry condition in which it has competition. It means that industry structure determines the behavior/conduct (strategy) of firms and the collective conduct then determine the collective performance of the firms in the industry [38]. In this view, firms have dimensions such as allocation efficiency, technical efficiency, and innovativeness. Since the structure is the prior cause of conduct and conduct itself is the cause of performance, in this chain conduct could be neglected and consider industry structure directly in trying to explain performance.

An essential branch of IO research is oligopoly theory; it's the study of the consequence of competitive interactions in a market where firm's actions affect its competitors [39]. This theory wanted to make clear the link between structure and inter-firm rivalry and provide difficulty determinants firms were facing in the market competition. It filled the gap of bipolar cases of pure competition and monopoly in the economist's view. Also, one influential framework for the analysis of competitive interactions was born, "game theory" $[40,41]$. Game theory found its place in IO as a section of oligopoly theory. Although these theories were so important in the strategic research and suggested systematic frameworks for assessing competition in an industry, they essentially attempt to focus on just one aspect of LCAG framework: external factors (opportunities and threats).

IO economic paradigm has had the highest impact in forming foundations of strategic thinking and research, but strategy practitioners have been skeptical of IO. Porter [42] outlines some of the most important ones: Frames of reference are different between practitioners and IO perspective; former is interested in the issues of an individual and unique company, latter focus on industry as a unit of analysis. Some research also explained that even in an industry firm perform differently. IO assumption was that all firms in an industry are identical. Hence, IO was not able to bring an answer for differential firm performance in the same industry. In addition, IO perspective was static. Although the static model is useful in the analysis of competition, most fundamental strategic issues for firms in the competition are not solely structure but structural changes (such as dynamics of concentration, entry barriers and so on). The main unanswered question in IO (Bain/Mason) perspective was "what are paths to such structure and what strategist can do about changes in this structure?" Moreover, traditional IO considered industry structure the sole determinant of firms conduct and performance. Thus firms are under the shadow of their industrial structures, and there is no room for change and innovation. But practical strategists, on the other hand, have realized that firms can change the structure of their industries through their actions. It was evident in the real world that there are often game changers that change the rules of industries. Furthermore, oligopoly theories were abstract, and most of the concepts were based on abstract experimental situations and not actual industries. All in all, these shortcomings made business strategists uncomfortable about embracing IO.

\section{Theories of the firm}

Economic thought has had a deep influence on thinking in the field of strategy. In particular, theories of the firm bring a viewpoint for thinking about organizational objectives and a framework for analyzing important firm and competition research problems. The main question regarding firms in the theory of the firm is that if markets are the effective forms of exchange "why firms exist?" and also "what are their boundaries and scope?" Here, we demonstrate the assumptions underlying of several economic theories of the firm for tracing the background in competition and strategy research.

\section{C.1 Neo-classical perfect competition}

In this view firm exist to combine resources to produce a product; Firm is assumed like a black box with some inputs which its output is a joint product of multiple inputs. In this neo-classical model, two main inputs are labor and capital. Perfect competition generally assumes that optimum input can be confirmed, all parties in the competition have complete information and resources are completely mobile and divisible. In this model since firms assumed to be identical, the objective of each individual firm in maximizing profit yields the whole market to equilibrium and thus zero economic returns for each firm.

\section{C.2 Chicago tradition}

The implicit theory of the firm in this tradition is that firms exist to enhance efficiency in production and distribution. From the theory of the firm's point of view in Chicago approach, when firms act together as a monopolist in the industry, their combined profits are maximized. However, Stigler [26] figures out that effective collusion requires costly control and enforcement, given that each party has an incentive to chisel on the agreement. Because of these high costs, Chicago school of thought holds that effective collusion is not likely to persist. So observed large size and above-normal returns are due to the firm's efficiency differential in production and distribution in comparison to competitors. Chicago perspective applies main concepts of neo-classical price theory - in particular profit maximizing and competition - while neglecting other central assumptions of perfect competition. One paramount role in this perspective is the entry of new 
competitors in imposing an imperative efficiency on incumbent firms and on determining long-run earnings potential. Although this view holds the efficiency based profits "need not be eliminated soon by competition" [27], in the long-term imitative entry will drive the firm's profits to zero.

\section{C.3 Coase/Williamson transaction cost theory}

Ronald Coase was the pioneer in this view who notes firms and market are alternative methods for coordinating production. Hence, the question to be answered in realizing the existence of firms is the basis for choosing between alternatives. The core of Coase's [28] analysis is that operation of market bring some cost, and by creating an organization and permitting some authority (an entrepreneur) to direct the resources, certain costs are preserved. In this view what is particularly important is the cost of negotiating contracts for inputs. Thus, firms exist to economize on the costs of conducting the same exchange between contractors.

One framework in this approach called "market failures" framework [29] which is based on Coase's work, challenges the traditional assumptions of the theory of the firm. From this perspective, the form of organization that develops in an exchange situation depends on the efficiency of that form for completing necessary transactions. This framework assumes decision-makers are opportunistic with bounded rationality. The fundamental characteristics of transactions between firms and consumers which impact how exchange process will be conducted are "asset specificity, uncertainty, and frequency" $[30,31]$. The most critical factor of these is asset specificity because investment in assets which are specific in a transaction make a commitment for both parties to the transaction for some period of time. When the productive assets are non- specific, a market contracting process is efficient. Thus this framework provides good insights about issues of firm existence and boundaries. Overall, this view considers the firm as a governance structure which is crafted to economize on transactions costs. Economies of scope [32] work and the role of asset specificity in producing benefits from technological innovation [33] are important examples of how the combination of this view with strategic management can extend knowledge in both fields.

\section{C.4 A behavioral theory of the firm}

This view in analyzing firms rejects the assumption of rationality of "economic man." The main focus of the behavioral theory of the firm is to predict price, output, and resource allocation decisions but with an clear focus on the actual process of organizational decision making [34]. One of the critics of traditional microeconomics view is Simon [35] who mentions the goal of an organization is not profit maximizing but 'satisfying' level of profits. He viewed organizations as a system of individuals with multiple goals who operate in a defined structure. Simultaneously, managerial decision making is limited because they cannot build comprehensive models of the world and also their information processing is limited: hence optimum (maximizing profit) is impossible since managers are characterized by "bounded rationality" when the encounter "uncertainty" and thus "behavioral rules" replace optimization.

Overall, the fundamental difference between the behavioral theory of the firm and more classic theories is in the treatment of rationality and uncertainty. In the determination of prices, outputs and resource allocation, the decision-making process is adaptively rational, with multiple objective and organizational learning.

\section{The Austrian school of thought}

Although traditional industrial organization economics has been one of the cornerstones of strategic thinking and research, many of its assumptions have come under widespread criticism. Some scholars have questioned the utility of IO concepts because of an inadequate theoretical foundation. IO largely neglects dynamical behavior and disequilibrium in the dynamic world of business. But there was another school of thought in economics that these characteristics were fundamental building blocks of it: "Austrian economics." In this school, the emphasis is on "the dynamic market process" and "entrepreneurial discovery" which are critical concepts for strategy research.

The concept of "the market process" tends to distinguish Austrian school. Unlike neo- classical theory that concentrates on equilibrium with the static snapshot of the nature of competition, Austrian economists view markets as processes of dynamic finding that move scattered information. They assume that earned profits of firms are through the entrepreneurial discovery. Austrian economists state that for the economy to land in equilibrium, innovations and discovery must be discontinuous (i.e., Its appearance is only in discontinuous clusters). They view innovation as a continuous process. Therefore, the market is never in equilibrium. Market inefficiencies enable a market not to be in equilibrium and are responsible for money making opportunities. From this perspective, the entrepreneur performs as an opportunity catcher or arbitrager. The entrepreneur sees an opportunity between what the resource market has to offer and what customers will be willing to pay. By taking advantage of this market inefficiencies, the entrepreneur receives the economic profits from the arbitrage.

Indeed, their main focus is on entrepreneur inspired by the desire for above-normal returns, as a motive for promoting discovery and catching opportunities in a constantly changing (disequilibrium) market. So, because competitors quickly imitate known strategies to generate above-normal returns till their return premium vanishes, these above-normal returns achieved by discovery are just temporary. This means that empirical modeling of business performance to find strategies (business laws and some sort of order) that firms can execute to achieve abnormal profits 'will be largely unsuccessful. Thus, because the returns to a given strategy dissipate, firms must adapt and respond to changing conditions'.[3] As such, flexibility becomes a critical strategic factor.

Indeed, business success is based on time and firm-specific unobservable factors. This school sees profits not as the consequence of monopoly power but rather as the result and 
incentive for discovery and innovation. Under this perspective, the goal of strategy formulation is not on limiting competitive forces but rather on the entrepreneurial discovery. Gluck, Kaufman, and Walleck [43] 'maintained that the essence of strategy is avoiding competition through an indirect approach'.

Schumpeter discussed the critical roles of entrepreneur and innovation in business success $[44,45]$. He contended that economic development occurs when firms implement new products, Production processes, and organizational techniques. In his view, the entrepreneur disrupts the market and push it toward out-of-equilibrium. Innovations come into the market and innovator out-competes rivals and earn profits. These abnormal profits provide the incentive but are short-lived. As innovations are imitated, economic profits dissipate and eventually vanish. Market returns to equilibrium until another innovation takes place. This dynamic process which shows moves from equilibriums to disequilibriums and vice versa is called "creative destruction." The profits achieved by innovation give the firm a time window to pursue new innovations. Thus, the forces of dynamic competition destroy any firm that merely attempts to maintain status quo. The Schumpeter's concept that sometimes market is in equilibrium distinguishes his perspective from Austrian mainstream.

\section{E. Evolutionary economics}

Evolutionary approaches have had a long history in economics, but they have never shaped a formal position in the mainstream of economics. In part, this has been due to the diversity of evolutionary views in theorizing in range of individuals to aggregates. It is also an issue of what it means to say that a theory is "evolutionary" in the first place: is it make sense the use of analogies to central concepts from evolutionary biology, or is it something altogether different? And if so, what is the status of such analogies [10]?

On a general level, the type of evolutionary theory that refers to the area of strategy brings analogies to the biological perspective of variation, inheritance, and selection. It tries to give a real-time entity of social and economic phenomena in terms of processes of change. Indeed, the process is an essential part of the evolutionary approach. Within this evolutionary view, companies have initially been modeled as possessing path- dependent knowledge units (routines). The concept of routines give a rationale for the relative robustness that is essential for the successful utilization of selection issues. There has been little tendency toward strategies that individual companies express on the basis of these knowledge fundamentals.

Nelson and Winter criticized IO because of its lack of attention to dynamic environment brought about by technological change [20]. The profits from successful innovation are disequilibrium phenomena that come from lead times over competition. The equilibrium analysis of IO does not depict anything about innovation and entrepreneurship. Nelson stated that if dynamic, disequilibrium, and institutional complexity are notable concepts of what is going on, then implications derived from the traditional theory must be viewed by suspicious [46]. But economically, the theory of Nelson and Winter is primarily, the same as its neoclassical counterpart, a theory of industries, with less focus on the company, due primarily to the importance it places on the selection environment. Indeed, 'evolutionary theory in the management context until recently has dealt with understanding the evolution of industries' [47].

In addition, there is a lack of attention in evolutionary view to firm behavior which is the suitable level that analogies to heredity should be found. Concepts like adaptation, learning, search, and path-dependence are mainly related to the level of the firm. Some number of attempts has been made to utilize evolutionary perspective to firm-level analysis. Some of these are depicted in the increase in publications regarding firm-level technology strategy from an evolutionary perspective. The increasing interest that Williamson's version of transaction cost theory has generated among evolutionary theorists is further evidence. Finally, one should mention Richard Nelson's in which the perspective has become more firm-oriented [48]. The fact that industry-perspective remains dominant in the realm of evolutionary view is due to the narrow description of the firm and its resources.

\section{F. Organizational ecology}

Until now we reviewed the economic models broadly in analyzing competition and strategy. We also noted some advantages and disadvantages of such models. One more perspective is called "organizational ecology." This dynamic framework is interested in the evolution of a system of interacting companies, in particular, how the population of them changes over time. The use of organizational/population ecology models [47] in strategy and competition is a clear example that how techniques and models from other disciplines might be useful.

In this perspective, based on the Darwinian concept of the "survival of the fittest" it proposes models that certain firms take positions that possess higher fitness than others in the population of firms. The premise here is that fittest firms will survive and others go out of business. The evolution of an industry can be modeled by considering how diverse types of firms compete over time, and how some population of firms survives longer than others. Behind organizational ecology is the notion that only limited resources are available in a market. This approach goes beyond industry analysis and suggests that certain positions within an industry can still be attractive even when there are dominant incumbents. This perspective provides the opportunity for the analysis of smaller firms and also the fact that some firms may fail.

Although organizational ecology tries to consider that firms are of certain types and therefore assumes that there is heterogeneity among companies, this characteristic is not modeled explicitly. Moreover, there is a high level of formalization in this perspective where mathematical relationships between variables are modeled. Also, there is a problem of translation from natural science definition of genotypes to firms as constituents of the population. Another problem is the fitness optimization that can be viewed as an analogy of utility maximization from within economics, and as 
I noted earlier there are common problems associated with maximization (e.g., "satisfaction" proposed by Simon) approaches within management science.

\section{STRATEGIC MODELS AND FRAMEWORKS}

\section{A. Structure-Conduct-Performance (SCP)}

At the heart of this view is this assumption that firm exists to hinder output through the monopoly power or collusive behavior with other firms. firms want to restrain output so that market price goes up and therefore successful firm will make a profit from the difference between this artificially high market price and its costs. From the economic point of view, these above-normal returns reflect the nefarious firm behavior that occurs at the expense of consumers. In this approach, a major focus has been empirical testing of "structure-conductperformance" hypothesis articulated by Bain [23, 24, 25]. In this hypothesis, structure of industry determines firm conduct (strategy) which in turn determines economic performance. Because firm conduct is supposed to be determined by industry structure, conduct is often neglected, and the association between structure and performance has been examined.

In this view motivation for expansion is increasing monopolization, or alternatively, preventing another firm from gaining monopoly control. Bain idea was that the notion of "perfect competition" 'sets the standard for traditional industrial organization and provides the foundation' for the premise that firms earn super-normal returns primarily by exercising monopoly power [23]. But, a big departure from perfect competition view is that this view encompasses the richer concept of firm heterogeneity; although perfect competition predicts that there are no persistent performance differentials when the market is in equilibrium, Mason/Bain IO holds an opposite approach. The assumption is that persistent above-normal profits are based upon long-lasting although limited types of heterogeneity between firms; based on different studies these heterogeneities come in the forms of dominance in firm size, market share and collusion in and between industries.

\section{B. Five forces framework and strategic groups}

After reviewing different types of economic formal frameworks and models, we focus now on more recently developed frameworks of competition and strategy. One of the most impactful contributions to the field of strategy and competitiveness was the work of Porter [1, 2]. In Porter's seminal work which its roots go back to the industrial organization and in particular, Structure-Conduct- Product paradigm [49], the main task of a strategist is to find the answer for two questions: where to compete (which industry)? How to compete? (defendable position in that industry). Indeed, Porter used IO concepts but from the frame of reference of a strategist. Although in IO the purpose of economists was how to grow competition, Porter reversed the point of view of that purpose and proposed a model under which how managers and firms could limit competition for higher returns. His Five Forces model asserts that there are five determinants that ascertain the attractiveness of an industry. The Five Forces are as follows: the bargaining power of the firms supplying the industry; the bargaining power of buyers; the threat of new firms potentially entering the market; the threat of substitute products; and the intensity of competitive rivalry.

In Porter's view, strategy means "positioning." Firms need to develop their strategies through a mixture of competitive dimensions, such as branding, pricing policy, higher product quality, better logistics, etc. these are enablers through which firms could gain an achievable and defendable position in an industry. This position enables the firm to gain above-average profits in the industry. Indeed, the meaning of strategy in this view is finding a defendable position that protects the firm's competitive advantage from actions of five forces that shape competition in the industry. Perhaps due to the influential effect of Porte's work in the 1980s, the basis of economics within strategy field has appeared to be unquestioned. In spite of strong features of this model, it has also been criticized because of its static nature. Hamel and Prahalad described this analysis as: "a snapshot of a moving car [50]. By itself, the photograph yields little information about the car's speed or direction whether the driver is out for a quiet Sunday drive or warming up for the Grand Prix."

In addition, Porter introduced the concept of strategic groups that followed the works of Hunt further developed by McGee and Thomas [2, 51]. In this concept firms that were in seemingly oligopolistic markets could be grouped into classifications. These firms remarkably follow similar strategies. Porter looked to the IO literature to give an explanation for this grouping of firms. In strategic groups framework firm are depicted on two-dimensional axes by their strategic attributes. One limitation of the strategic groups framework is that it considers the positioning of firms within this strategy space at one moment in time, and does not take into account the dynamics of the changes of position over time, changes that can be as a result of the reactions of one firm's positioning affecting the subsequent positions of firms over time.

\section{The resource-based view of the firm}

Another main attempt to explain differences between firms, their heterogeneity, came from the resource-based view of the firm. Scholars such as $[12,56]$ see resources as being the most important components of a firm. Wernerfelt developed the notion of the resource-based view of the firm, building on the work of Penrose that perceived a firm as a bundle of resources [12]. The work of Penrose is considered a very fundamental and impactful one as a basis in this framework. Other notable contributions include $[8,9,20,32,58,59,60]$. Like early strategy scholars, these authors are primarily interested in differences across firms. What differentiates them is their use of economic reasoning, notably the economics of Ricardian and Paretian rents. In particular, the question of why some firms earn supernormal profits has received careful consideration. While theoretical and empirical research in industrial organization economics has shown that a firm's profits are related to its choice of $[3,61]$, resource-based reasoning examines this question from the perspective of interfirm differences. 
The central assumption underlying resource-based theory is heterogeneity of resources. It means resource bundles and capabilities of production are heterogeneous among companies [56]. This concept implies that since resources are heterogeneously distributed among firms, and these resources are not in unlimited supply and are scarce, firms with superior resources will gain rents. It's the known Ricardian rent. The crucial notion is that the supply of "superior" resources remains limited. So, efficient firms with superior resources can sustain this competitive advantage just by their resources that can't be developed freely or be imitated by competitors. What make distinction of monopoly profits from Ricardian ones is that monopoly profits is the outcome of restriction of output rather than an inherent scarcity of resource supply.

In resource-based view, sustained competitive advantage needs the condition of heterogeneity be maintained. If it's a short-lived phenomenon, profits will be ephemeral as well. Since firms are primarily looking for consistent and long-term rents, the condition of heterogeneity must be durable to add value. So there must be mechanisms which restrict competition for those type of rents. Rumelt introduced 'isolating mechanisms' 'which protect individual firms from imitation and preserve their rent streams' [59]. Another notion is causal ambiguity [58]. This means the uncertainty regarding the causes of efficiency differences among firms. There are very important contributions for isolating mechanisms and defying imitation in the literature including [9, 33, 49, 59, 62, 63, 64]. In spite of its considerable advancement, the resource-based view has some number of weaknesses. A case in point is that it's often difficult to recognize which resource or combination of resources accounts for firm's successful performance in the real world. This difficulty in assessment is likely due to the fact that it is impossible to measure them in isolation. As Porter noted, resources are valuable only if they "allow firms to perform activities that create advantages in particular markets" [21]. Another important contextual factor is the issue of resource complementarity. It means resources are contingent on other resources, so the system of resources is matter. Furthermore, the value of resources changes over time.

In addition, resource-based view theory of the firm applies both process and equilibrium constructs, although inconsistencies between these are rarely acknowledged. Indeed resource-based view roots go back to a neo-classical theory which is clear in the equilibrium concept of sustainable competitive advantage [8]. On the other hand, many of the more practical contributions [65] deal explicitly with the process. So there is a need for further research regarding more precise definitions of resources and capabilities and also solving the conflict between dual concepts of equilibrium and process taken in this theory.

\section{Delta framework}

It is evident in the literature of strategy that Porter's industry analysis and the resource-based view (RBV) of the firm have had the highest impact and attention. From these perspectives, firms should either find an attractive industry and position accordingly or excel on unique resources and capabilities. Although these frameworks have often been considered conflicting rather complementary, Hax and Wilde focused on the complementarity of views and propose a model called "Delta"( Delta is a Greek letter means transformation and change) [90]. But they contend that one missing piece in both of these frameworks is the "customer." Hax and Wilde mention that "If you take Porter literally, the customer is represented by the "Buyer" - one of the Five Forces - whose bargaining power we should resist or diminish [90]. In that respect, the customer constitutes an additional element of the rivalry that we need to overcome. In the ResourceBased View of the Firm, there is no explicit mention of the customer." They assert that in the internet era, linking customer and enterprise through using network technology creates new sources of strategic options. Hax and Wilde contend that their Delta model is integrative of two main prior frameworks in strategy [90]. They say: " Porter's framework and the Resource-Based View differ in explaining the sources of profitability. Porter associates it with monopolistic rent that flows from industry structure. The Resource-Based View of the firm ties it to the corporation's internal capabilities. They share the perspective that business is akin to war and that designing business strategy is akin to playing a zero-sum game. Profitability accrues to those who are superior to their competitors. The Delta Model takes issue with this almost obsessive focus on competition." It is also clear that at the heart of Delta model is a customer. They explain it this way: "We believe that a firm owes itself to its customers. They are the ultimate repository of all the firm's activities. At the heart of management and, certainly, at the heart of strategy, besides the customer. We have to serve the customer in a distinctive way if we expect to enjoy superior performance. The name of the game is to attract, to satisfy, and to retain the customer." They put the "customer bonding" concept at the center of strategy formulation. According to their view, they propose three strategic options for firms: "system-lock in" under which firms make proprietary platforms that lock-out other competitors, "total customer solutions" that based upon firms reduce customer costs or increase their profits, "best product" which options are low-cost or differentiation. Finally, they suggest their winning formula as follows [90]:

- "Concentrate on the customer. Start with a careful segmentation of your customer base and develop as much knowledge as possible of the customer economics. Remember that the primary objective is to seek customer bonding.

- $\quad$ Select the most appropriate strategic positioning among the three key options - Best Product, Total Customer Solutions, and System Lock-In - that will result in a customer value proposition with the highest possible bonding.

- Define the strategic agenda that determines the action program to implement your desired strategic option. Assure the proper alignment with the three adaptive processes - Operational Effectiveness, Customer Targeting, and Innovation.

- Design the proper metrics and rewards to facilitate the strategy development." 


\section{E. Game theory and co-opetition}

The concept of rational decision makers who can make decisions that maximize their utility is the basis of game theory. Game theory is about understanding reactions of competitors to your actions. If we think from the competitor's point of view, we are able to make decisions that are better than when we think in isolation as a stand-alone player. The application of game theory in strategy and management has been widespread [52] whereby more than one player interacts with other players by playing certain strategies; outcomes of plays are depicted in "payoff" matrices. The crucial aspect of the game theory is that your payoff depends on the strategies of your competitors. There are central assumptions in game theory: the competitor will behave rationally and will try to win; the competitor is independent in relation to other competitors; competitors are aware of the interdependencies and the actions that competitors could do. To benefit from game theory, strategists need to put themselves in the position of their competitors; they need to take an informed view on the likely competitor actions and choose the best course of action. Also, Brandenburger and Nalebuff applied the concept of game theory to business under the name of 'Co-opetition' [53]. They simultaneously considered competitors in an industry competitor and cooperator. They assert that if the firm is seen of this view, this may benefit all firms in the industry.

Game theory created high expectations in the field of strategy as an analytical tool for analyzing the dynamics of interaction between firms. But, this early promise has not entirely come into reality with strategy work. There are several reasons for this issue. First, in order to make game theory models relevant, the firms under consideration should be the same size. Second, there are only a limited number of strategies that firms can play. Third, the focus is on the equilibrium outcome, although contemporary game theory research on repeated games addresses this problem [54]. However, these recent developments largely have been in economics world and not strategy field. In Porter's paper 'Towards a Dynamic Theory of Strategy' [21], he mentions that although game theory may be seen as dynamic, in that there is a sequence of actions made by firms, this is not a dynamic theory: 'by concentrating sequentially on small numbers of variables, the models fail to capture the simultaneous choices over many variables that characterize most industries. The models force homogeneity of strategies. Yet it is the trade-offs and interactions involved in configuring the entire set of activities in the value chain that define distinct competitive positions. Finally, the models hold fixed many variables that we know are changing.'

Moreover, most of game theory models rest on the assumption that the players are perfectly rational: it means the predictability of competitor's actions and thus playing optimal strategies. In addition, much of the research in game theory is used to determine Nash equilibrium: where no one player has an incentive to deviate from their equilibrium strategy. However, it should be asked whether such assumptions can provide a suitable methodology for analyzing problems in the real world of business or for the competitive system which often is not in equilibrium.

\section{F. Dynamic Capabilities}

One of the criticisms to resource-based view of the firm is that it neglects the external environment. Also, the notion that the distribution of resources remains stable over time does not provide a realistic notion of interfirm competition in high turbulence times when the resources that may have been the source of competitive advantage in the past may now not be of use. Moreover, there is much confusing terminology, sometimes conflicting, within the area of resource-based view of the firm.

Indeed, Teece in their key work on dynamic capabilities goes so far as to say "we do not like the term "resource", and believe it is misleading' [19]. So scholars extended the resource-based view of the firm and proposed the notion of dynamic capabilities. The same as resource-based view, terminology definition in dynamic capabilities is also difficult. Dosi describes the 'terminological anarchy' of the resourcebased view: "the term "capabilities" floats in the literature like an iceberg in a foggy Arctic sea, one iceberg among many, not easily recognized as different from several icebergs nearby' [66]. Makadok uses the rather obvious definition of resources: 'organizationally embedded non- transferable firm-specific resource whose purpose is to improve the productivity of the other resources possessed by the firm' [67]. Teece defines dynamic capabilities as 'the firm's ability to integrate, build, and reconfigure internal and external competencies to address rapidly changing environments' [19]. This definition considers both the resource-based view and the notion of rapidly changing environments. Teece asserts that 'capabilities cannot easily be bought; they must be built.' Although resources can be 'picked' in order to bring them within the firm, capabilities are different: they are built not acquired - capabilities are embedded within the organization whereas resources are not. Winter distinguishes between 'ordinary' organizational capabilities and dynamic capabilities [68]. Putting his definition on his earlier work with Nelson [20], organizational capabilities are defined as a 'high-level routine (or collection of routines) that, together with its implementing input flows, confers upon an organization's management a set of decision options for producing significant outputs of a particular type', basing the concept on routines: 'behavior that is learned, highly patterned, repetitious, or quasi-repetitious, founded in part in tacit knowledge - and the specificity of objectives'. What makes dynamic from ordinary capabilities is that dynamic capabilities are concerned with change and learning. The concept is that dynamic capabilities determine change rate of organizational capabilities.

Eisenhardt and Martin contend that dynamic capabilities are of several types: firms may use dynamic capabilities to create, integrate, recombine, and release resources from the firm [57]. They also distinguish between dynamics capabilities in 'high velocity' and stable markets situations: in high-velocity environments, dynamic capabilities are experiential (i.e., not analytic), iterative (i.e., non-linear), and are inherently simple in nature. In markets that are moderately dynamic, they suggest that dynamic capabilities become efficient and robust routines become embedded in cumulative, existing knowledge within the firm. In other words, effective dynamic capabilities enable a firm to adapt to a changing and turbulent 
environment. They assert that although dynamic capabilities are idiosyncratic, 'they exhibit commonalities or 'best practice' across firms. Their broad structural patterns vary with market dynamism, ranging from the robust, grooved routines in moderately dynamic markets to fragile semi-structured ones in high- velocity ones. They evolve via well-known learning mechanisms.' They finally conclude that lies in resource configurations, not dynamic capabilities. Teece suggests that 'Further theoretical and organizational work is needed to tighten the framework, empirical research is critical to helping us understand how firms get to be good, how they sometimes stay that way, why and how they improve, and why they sometimes decline' [19].

\section{G. Hyper-competition and Environmental Turbulence}

The turbulent competitive environment is precisely the opposite of stable landscape. In such industries, the roles of different competitors are blurred. They rely on more complex and diverse combination of competitive dimensions at the time of designing their competitive strategies. This makes prediction rather difficult, and in some conditions misleading. These landscapes require new ways of thinking about competition and industry dynamics. The dynamic capabilities approach mentioned earlier has been an attempt to respond to the challenges posed by the turbulent competitive environment. As we saw in [19] seminal definition of dynamic capabilities, firms may have to deal with rapidly changing environments. This concept has been used by diverse words: turbulence, highvelocity environments, and hypercompetitive environments [69].

D'Aveni depicts the notion of 'hyper-competition' - a state that is defined as: "[resulting] from the dynamics of strategic maneuvering among global and innovative combatants [69, 70]. It is a condition of rapidly escalating competition based on price- quality positioning, competition to create know-how and establish a first-mover advantage, competition to protect or invade established a product or geographic markets, and competition based on deep pockets and the creation of even deeper pocketed alliances the frequency, boldness, and aggressiveness of dynamic movement by the players accelerate to create a condition of constant disequilibrium and change, in other words; environments escalate toward higher and higher levels of uncertainty, dynamism, heterogeneity of the players, and hostility'.

D'Aveni assumes that there is a new type of competition - 'hyper-competition,' completely different from the traditional notion: 'in the old days of stable environments, companies created fairly rigid strategies designed to fit the long-term conditions of the environment' [69]. D'Aveni's idea is that competitive equilibrium was in the past where "less dominant firms accepted their secondary status because they were given the opportunity to survive by a leading firm that avoided competing too aggressively." One major reason to focus on turbulent environments has been the static nature of strategy and competition frameworks but dynamic nature of the environment. Teece asserts that existing models for analyzing strategy have not proved useful at understanding sources of competitive advantage in times of rapid change [19]. If we observe that the business environment in the real world is dynamic and complicated, it's not reasonable to consider models developed under concepts of equilibrium, stability, and linearity.

Hence, several scholars suggested different concepts for making strategy in a turbulent environment. Hamel and Prahalad propose the concept of "strategic intent" for guiding strategy [50]. According to their idea, strategic intent is the overall direction of a company that captures the essence of winning, is stable over time, and sets a goal that deserves personal effort and commitment. This thought brings to mind a stable and systematic pattern that take the company toward a valuable and determined target. Bourgeois and Eisenhardt suggest the "imitation" strategy for surviving in the turbulent environment [71]. In this strategy, follower goes towards the position of leader. Brown and Eisenhardt assert that such movement should be made incrementally [72]. Rivkin suggests the imitation of complex strategies [73]. He applies NK model in his analysis and assumes that there is interconnectedness between strategies. Overall, these studies show that the ability of rapid and continuous change is a crucial capability in high- velocity markets.

\section{LIMITATIONS OF CLASSICAL ECONOMIC-BASED APPROACH}

The formalization of economic models is actually based on explicit nature of model that brings a certain amount of rigor to the formulation process. However, there are important limitations when the economic view is used, particularly in the way that equilibrium is an assumption of this framework. Also, when firms in an industry are supposed to be homogenous, and the emphasis is on stasis. These limitations are significant in using this framework in strategic management. It's crystal clear that most industries are not in an idealized form of equilibrium and the notion of how to deal with "turbulent" and maybe "hyper-competitive" environments is an active area of research.

Economic models introduced earlier essentially assume equilibrium outcomes. This thought that competitors finally will settle down into a stasis can only be applicable in an idealized competition where there is nothing more than pushing and knocking out competing firm out of equilibrium. One of the core tenets of neo-classical economics also is assumed in many models, "rationality." According to this assumption actors (such as firms) will behave in a way that maximizes their utility under the given constraints. But, actors in the real world such as strategists do not always behave rationally - they may follow 'boundedly rational' behavior [35], and not optimize their utility functions. Simons contends that firms follow to get a level of "satisfaction" in their objectives and don't necessarily maximize their utility. Indeed, Porter himself [21] notes: "it is well known that [industrial organization] models are highly sensitive to the assumptions underlying them and to the concept of equilibrium that is employed." Moreover, while game theory was seen as a potential field for modeling dynamics of strategy and competition, the involving of more than two firms into the market poses additional problems. One firm among many of firms may move and perturb the entire competitive system. 
In addition, economic models suppose that the world jumps immediately to an equilibrium. But one main point that is not considered is the path to equilibrium. Also, this equilibrium assumption means there are not any space for innovation and no incentive for firms to change strategies. It seems these models are considered to exist in isolation, where there are no environmental shocks, or indeed external environment does not have any effect on the system for pushing it out of equilibrium. Knott introduces the problem: 'the goal of the strategy is persistent profits - in short, to overcome the microeconomic equilibrium of homogeneous firms with zero profits' [55]. More specifically, this equilibrium is rather the equilibrium of the model than we observe in the real world.

One more problem in using the microeconomic approach in modeling strategy issues is its over-emphasis on the homogeneity of firms. This assumption eliminates the possibility of analyzing the impact of differences between firms on their performance in an industry. More recent theoretical approaches in formulating competition and strategy such as resource-based view (RBV) of the firm $[8,56]$ and the dynamic capabilities approach $[19,57]$ are specifically focused on realizing how intrafirm heterogeneity leads to differences in firm's strategies and performance.

\section{COMPETITIVE DYNAMICS WORKAROUND}

The research stream of competitive dynamics which its intellectual roots go back to Schumpeter's concept of creative destruction has progressed in recent years in the mainstream literature of research on strategy and competition. The focus of this view is on dynamic processes by which firms act upon and react to one another in the pursuit of market opportunities. Firms act and competitors respond, and these interactions determine survival and long-term performance. 'Similarly, the Austrian school of economics [74, 75, 76] considered competition to be a dynamic market process rather than a static market condition.' The core is the process by which market moves. It's this movement and not an equilibrium that is taken to be of interest. Also based on this school of thought, since the market is in disequilibrium advantage is a limited temporal window for exploitation, so it is transient $[77,78]$.

According to definitions, the competitive dynamic is the study of inter-firm hard competition based on specific "competitive actions and reactions," their strategic and organizational context, and their motives and outcomes [79, 80]. The intent of this perspective has been mainly to address more fine-grained questions regarding competition: how do firms act and rivals react when they compete? Why some firms compete in a particular way? How do competitive interactions influence performance and vice versa $[81,82]$ ?

In the field of strategic management, seminal works of MacMillan \& Von and Bettis \& Weeks's used this frame of reference $[83,84]$. They were the beginning of competitive dynamics research in the realm of strategy. Other works followed these earlier studies. The main premise of this stream of research is that it can provide a useful integrative framework for strategy by bridging micro-actor and macro- competitive viewpoints. Chen outlined five research themes in this field
[85]: "(1) competitive interaction: action-level studies; (2) strategic competitive behavior and repertoire: business-level studies; (3) multimarket and multi-business competition: corporate-level studies; (4) integrative competitor analysis; and (5) competitive perception. "There are also some studies in integrating competitive dynamics and RBV frameworks $[86,87,88]$. However, there are several gaps in this stream of research that one of the most important for example is integrating micro and macro perspectives [89].

\section{TOWARD THE ECONOMICS OF COMPLEXITY}

We have reviewed several models from different perspectives in earlier sections. What is clear is that most of them are based on paradigms of equilibrium, linearity, rationality, optimization, etc. We may need more systematic views which are based on disequilibrium, nonlinearity, behavioral rules, networked interaction and so forth. One promising area that might address such phenomena in the analysis of competition and strategy is complexity science, and in particular, the economics of complexity.

Complexity has arisen as a new unifying and systematic theory to understand the nature of commonalities and change across a variety of disciplines ranging from mathematics, physics, biology, economics, social science, etc. complexity takes a systemic approach under which nonlinear interactions among agents (constituents of system) in micro level will result in macro and emergent behaviors that cannot be realized just by studying agents. Complexity builds on some assumption:

Heterogeneous agents; means agents are intrinsically heterogeneous by character. Local information means knowledge of agents is local and no one can have the information of the whole system. Non-linearity; interactions among agents are non-linear in nature. Systemic interdependence; result of the behavior of individual agent is dependent on the chain of communications in the system. Phase transition; small changes in the parameters of the system change the behavior and outcomes as the system goes from changing its phase. Non-ergodicity; means a little trigger at a particular point in time impacts the long-term dynamics of a system. Emergent properties; properties of a system that arise at the aggregate level; simply put, means whole is greater than some of the parts. A core aspect of complexity is how interacting agents produce system-level patterns that those agents in turn react to. This leads to the emergence of aggregate properties and structures that are not observable at lower levels. There is a review of complexity theory applications to economics in [91, 92, 93, 94, 95, 96]. It has been asserted that complexity is very frequent in economic issues [97]. Based on equilibrium concept and reductionist approach in classical economics, aggregation is simply the sum of parts. It means dynamics of a system is the only simple sum of the dynamic of constituent parts. This view clearly does not consider interdependencies and positive/negative feedbacks in the interaction of parts. What classical models fail to realize is correct view toward aggregation where the concept of "emergence" enters the scene. Schelling notion [98] of emergence means the spontaneous formation of self-organized patterns at different levels of a hierarchy [99]. Simon explain a 
complex system in this form: "Roughly, by a complex system I mean one made up of a large number of parts that interact in a non- simple way [100]. In such systems, the whole is more than the sum of the parts, not in an ultimate metaphysical sense, but in the important pragmatic sense that, given the properties of the parts and the laws of their interaction, it is not a trivial matter to infer the properties of the whole. In the face of complexity, an in-principle reductionist may be at the same time a pragmatic holist."

From the perspective of complexity, ABM (agent-based modeling) can be used as a bridge between micro and macro. In $\mathrm{ABM}$ models aggregate outcomes (the whole, e.g., the differential firm performance) are estimated as the sum of individual characteristics (its parts, e.g., firm's size). However, system-level behavior is often distinguishable from the behavior of agents which make up the whole, resulting to the discovery of emergent properties $[101,102]$. In this view, the whole is greater than the sum of parts. Also, it might happen in a way that seems system follow a distinct logic, with its objectives and means. ABM provides a technique that allows systematic analysis of dynamics and emergent properties at the macroscopic level. The ABM methodology introduced by complexity stream of research uses bottom-up approach and is focused on the interaction of many heterogeneous agents, which may produce a statistical equilibrium. [94, 95, 103, 104, 105]. ABM allows making models with heterogeneous (e.g. heterogeneous firm in competition) agents based on simple behavioral rules and interactions (e.g. competitive behaviors) between them, where the resulting systemic and macro dynamics and empirical regularities (e.g., statistical equilibrium, maybe we can call it, differential firm performance) are not known and deductible from behavior of agents [106]. This system doesn't always need to be in equilibrium (assumption of most economic models) and based on interactions could change its phase and goes from one equilibrium to another. What is surprising in this perspective is that it has both views of IO and Austrian schools in itself. It is dynamic processes (Austrian) that give rise to emergent (e.g., creative destruction) properties, and simultaneously system can sometimes be in equilibrium (IO view). So I assert that these prior perspectives in modeling competition are not contradictory, but each one of them only points to one aspect of the problem. Complexity perspective and in particular ABM provides the significant potential to model and understand the dynamics of competition and strategy. Identification of the advantages of such approach has been highlighted in social science has been highlighted in the literature as well [107, 108, 109].

\section{COMPARISION OF STRATEGIC PERSPECTIVES}

From a historical review of different perspective regarding strategy and competition it's explicitly evident that most of proposed models and theories are derived from three economic approaches: industrial organization economics, Austrian economics, and evolutionary economics. In this regard, existing perspectives and tools available in the economics of complexity can bring value to the research field of strategic management. In addition, as shown in table I, important models of strategy in the realm of strategic management research evolved from static to more dynamic approaches. Therefore, it reveals that deriving perspectives from system theories and science of complexity and complex systems can add to the toolbox of strategy scholars and they can dig deeper in realizing dynamics processes and behaviors that create outof-equilibrium conditions.

\section{CONCLUSION}

There are many frameworks and models of competition and strategy that have made significant steps towards unifying and integrating different aspects of competition. While most of them are based on economic paradigms and models, some of them adopted views from other fields of science such as sociology, systems science, psychology, biology, etc. after reviewing different frameworks of competitive behaviors and strategy in the literature we contend that models have used different perspectives and frames of reference in response to the differential firm performance within and across industries, but all of them are trying to answer the original issue in strategy realm. There exist both commonalities and contradictions among proposed frameworks. Most of them are based on economic theories of the firm, but some applications from other fields of study are evident. Fundamental issues such as rationality, unit of analysis, used research methods, equilibrium, level of aggregation and dynamics require further research in the field. But one thing is evident from the evolution of strategy frameworks that models proposed intended to be more dynamic. For further research, we suggest scholars pay attention to different frameworks systematically and attempt to unify and integrate these fragmented perspectives. Strategy researchers must approach interdisciplinary research with rigor, with a firm grounding and understanding of the relevant theories and techniques from other fields which they seek to integrate with strategy. Because the final goal of the strategy is to find a systematic and dynamic theory which can consider different features of competition and strategy in a unified model (consider internal and external), and also could explain differential firm performance and competitive advantage. Although because of complex and dynamic business idiosyncrasies in time and space, such natural laws of strategy may not be guaranteed. We can be hopeful to find some patterns on macro levels that are useful. 
TABLE I. MODEls OF StRategy Within Static TO MORE DYNAMIC APPROACHES

\begin{tabular}{|c|c|c|c|c|c|c|c|}
\hline & Basic assumption & $\begin{array}{l}\text { Level of } \\
\text { analysis }\end{array}$ & origin & Focus & $\begin{array}{l}\text { Competitive } \\
\text { Advantage }\end{array}$ & $\begin{array}{l}\text { Competitive } \\
\text { strategy }\end{array}$ & $\begin{array}{c}\text { Dynamic } \\
\text { consideration }\end{array}$ \\
\hline $\begin{array}{l}\text { Structure- } \\
\text { Conduct- } \\
\text { Performance }\end{array}$ & $\begin{array}{l}\text { Industry structure } \\
\text { determines } \\
\text { competition and } \\
\text { profitability }\end{array}$ & $\begin{array}{l}\text { Macro } \\
\text { industry }\end{array}$ & $\begin{array}{l}\text { Industrial } \\
\text { organization } \\
\text { economics }\end{array}$ & $\begin{array}{c}\text { Structure } \\
\text { determines } \\
\text { strategy and } \\
\text { then } \\
\text { performance }\end{array}$ & $\begin{array}{l}\text { Can be } \\
\text { created and } \\
\text { sustained }\end{array}$ & $\begin{array}{c}\text { A } \\
\text { mathematical } \\
\text { model with an } \\
\text { equilibrium } \\
\text { solution } \\
\end{array}$ & $\begin{array}{l}\text { Competition in an } \\
\text { industry }\end{array}$ \\
\hline $\begin{array}{l}\text { Five-Force } \\
\text { analysis }\end{array}$ & $\begin{array}{l}\text { Industry structure } \\
\text { determines } \\
\text { competition and } \\
\text { profitability }\end{array}$ & $\begin{array}{c}\text { Macro } \\
\text { industry } \\
\text { level }\end{array}$ & $\begin{array}{l}\text { Industrial } \\
\text { organization } \\
\text { economics }\end{array}$ & $\begin{array}{l}\text { Five forces } \\
\text { that make up } \\
\text { the industry } \\
\text { structure }\end{array}$ & $\begin{array}{l}\text { Competitive } \\
\text { advantage } \\
\text { can be } \\
\text { created and } \\
\text { sustained } \\
\end{array}$ & Generic types & $\begin{array}{l}\text { Comparison between } \\
\text { two-time points. } \\
\text { Industry in } \\
\text { equilibrium }\end{array}$ \\
\hline RBV & $\begin{array}{l}\text { Firms in the same } \\
\text { industry perform } \\
\text { differently because, } \\
\text { even in equilibrium, } \\
\text { firms differ in terms of } \\
\text { resources and } \\
\text { capabilities they } \\
\text { control }\end{array}$ & $\begin{array}{l}\text { Companies } \\
\text { and } \\
\text { businesses }\end{array}$ & $\begin{array}{l}\text { Ricardian rents and } \\
\text { Penrosian theory of } \\
\text { the growth of the } \\
\text { firm }\end{array}$ & $\begin{array}{l}\text { Bundle of } \\
\text { resources } \\
\text { among firms }\end{array}$ & $\begin{array}{l}\text { Competitive } \\
\text { advantage } \\
\text { can be } \\
\text { created and } \\
\text { sustained }\end{array}$ & $\begin{array}{l}\text { Excel on } \\
\text { unique and } \\
\text { scarce } \\
\text { resources and } \\
\text { capabilities }\end{array}$ & $\begin{array}{l}\text { Uses both } \\
\text { equilibrium and } \\
\text { process concepts }\end{array}$ \\
\hline Delta model & $\begin{array}{l}\text { The customer is at the } \\
\text { heart of management } \\
\text { and strategy }\end{array}$ & $\begin{array}{l}\text { Companies } \\
\text { and } \\
\text { businesses }\end{array}$ & Five forces and RBV & $\begin{array}{l}\text { Customer } \\
\text { Bonding }\end{array}$ & $\begin{array}{l}\text { Competitive } \\
\text { advantage } \\
\text { can be } \\
\text { created and } \\
\text { sustained }\end{array}$ & $\begin{array}{l}\text { Best customer } \\
\text { solution, } \\
\text { system-lock in, } \\
\text { and best } \\
\text { product }\end{array}$ & $\begin{array}{l}\text { Not clear idea about } \\
\text { dynamics of market }\end{array}$ \\
\hline $\begin{array}{l}\text { Game } \\
\text { theory }\end{array}$ & $\begin{array}{l}\text { Competitive } \\
\text { interactions between } \\
\text { competitors }\end{array}$ & $\begin{array}{l}\text { Inter-firm } \\
\text { competition }\end{array}$ & $\begin{array}{l}\text { Industrial } \\
\text { organization } \\
\text { economics }\end{array}$ & $\begin{array}{l}\text { Reactions of } \\
\text { competitors to } \\
\text { your actions }\end{array}$ & $\begin{array}{c}\text { No clear idea } \\
\text { about } \\
\text { sustainability } \\
\text { of } \\
\text { competitive } \\
\text { advantage }\end{array}$ & $\begin{array}{c}\text { Playing } \\
\text { different } \\
\text { competitive } \\
\text { games }\end{array}$ & $\begin{array}{l}\text { Analytical tool and } \\
\text { equilibrium outcomes }\end{array}$ \\
\hline $\begin{array}{c}\text { Dynamic } \\
\text { capabilities }\end{array}$ & $\begin{array}{c}\text { Importance of } \\
\text { dynamic processes, } \\
\text { including acquisition, } \\
\text { development, and } \\
\text { maintenance of } \\
\text { differential bundles of } \\
\text { resources and } \\
\text { capabilities over time }\end{array}$ & $\begin{array}{l}\text { Companies } \\
\text { and } \\
\text { businesses }\end{array}$ & Penrose and RBV & $\begin{array}{c}\text { Dynamic } \\
\text { capabilities }\end{array}$ & $\begin{array}{l}\text { Competitive } \\
\text { advantage } \\
\text { can be } \\
\text { created and } \\
\text { sustained }\end{array}$ & $\begin{array}{l}\text { Learning and } \\
\text { reconfiguration } \\
\text { of bundle of } \\
\text { resources }\end{array}$ & $\begin{array}{l}\text { Changing and } \\
\text { dynamic market } \\
\text { environments }\end{array}$ \\
\hline $\begin{array}{l}\text { Hyper- } \\
\text { competition }\end{array}$ & $\begin{array}{c}\text { Strategic maneuvering } \\
\text { in hyper-competitive } \\
\text { markets }\end{array}$ & $\begin{array}{l}\text { Rivalry } \\
\text { among } \\
\text { firms }\end{array}$ & Austrian economics & $\begin{array}{l}\text { Turbulent and } \\
\text { hyper- } \\
\text { competitive } \\
\text { environments }\end{array}$ & $\begin{array}{l}\text { Transient } \\
\text { and } \\
\text { ephemeral } \\
\text { competitive } \\
\text { advantage }\end{array}$ & $\begin{array}{l}\text { Strategic intent } \\
\text { and imitation }\end{array}$ & $\begin{array}{l}\text { Non equilibrium } \\
\text { competition }\end{array}$ \\
\hline $\begin{array}{l}\text { Competitive } \\
\text { dynamics }\end{array}$ & $\begin{array}{l}\text { Dynamic competition } \\
\text { and action/reaction of } \\
\text { firms determine } \\
\text { performance }\end{array}$ & $\begin{array}{l}\text { Micro firm } \\
\text { actions }\end{array}$ & $\begin{array}{l}\text { Theoretical/empirical } \\
\text { work extended from } \\
\text { Schumpeter and } \\
\text { Austrian economics }\end{array}$ & $\begin{array}{l}\text { Individual or } \\
\text { dyadic action } \\
\text { of firms }\end{array}$ & $\begin{array}{l}\text { Competitive } \\
\text { advantage is } \\
\text { ephemeral } \\
\text { and relative } \\
\text { advantages } \\
\text { exist }\end{array}$ & $\begin{array}{l}\text { Dynamics of } \\
\text { actions and } \\
\text { reactions }\end{array}$ & $\begin{array}{l}\text { Competitive } \\
\text { interactive behaviors } \\
\text { between two firms }\end{array}$ \\
\hline
\end{tabular}

\section{REFERENCES}

[1] J. B. Barney and A. M. Arikan, "The resource-based view: Origins and implications," Handbook of strategic management, vol. 124188, 2001.

[2] C. Zott, "Dynamic capabilities and the emergence of intraindustry differential firm performance: insights from a simulation study," Strategic Management Journal, vol. 24, no. 2, pp. 97-125, Feb. 2003.

[3] M. Porter, "How Competitive Forces Shape Strategy," Harvard Business Review, vol. 57, no.2, pp. 137-45, 1979.

[4] M. E. Porter, "Competitive Strategy: Techniques for Analyzing Industries and Competitors," 1980.

[5] R. Schmalensee, "Do Markets Differ Much?," American Economic Review, vol. 75, no.3, pp. 341-51, 1985.

[6] R. P. Rumelt, "How much does industry matter?," Strategic Management Journal, vol. 12, no.3, pp. 167-185, 1991.
[7] A. M. McGAHAN, M. E. Porter, "How Much Does Industry Matter, Really?," Strategic Management Journal, vol. 18, no.S1, pp. 15-30, 1997.

[8] A. M. McGahan, "The Performance of US Corporations: 1981-1994," The Journal of Industrial Economics, vol. 47, no.4, pp. 373-398, 1999.

[9] R. Amit, P. J. H. Schoemaker, "Strategic assets and organizational rent," Strategic Management Journal, vol. 14, no.1, pp. 33-46, 1993.

[10] J. B. Barney, "Strategic Factor Markets: Expectations, Luck, and Business Strategy," Management Science, vol. 32, no.10, pp. 12311241, 1986.

[11] I. Dierickx, K. Cool, "Asset Stock Accumulation and Sustainability of Competitive Advantage," Management Science, vol. 35, no.12, pp. 1504-1511, 1989. 
[12] E. Penrose, C. Pitelis, "The Theory of the Growth of the Firm," (4 edition). Oxford ; New York: Oxford University Press, 2009.

[13] M. A. Peteraf, "The cornerstones of competitive advantage: A resource-based view," Strategic Management Journal, vol. 14, no.3, pp. 179-191, 1993.

[14] B. Wernerfelt, "A resource-based view of the firm," Strategic Management Journal, vol. 5, no.2, pp. 171-180, 1984.

[15] D. C. Galunic, K. M. Eisenhardt, "Architectural Innovation and Modular Corporate Forms," Academy of Management Journal, vol. 44, no.6, pp. 1229-1249, 2001.

[16] R. Henderson, I. Cockburn, "Measuring Competence? Exploring Firm Effects in Pharmaceutical Research," Strategic Management Journal, vol. 15, no.S1, pp. 63-84, 1994

[17] M. Iansiti, K. B. Clark, "Integration and dynamic capability: evidence from product development in automobiles and mainframe computers," Industrial and corporate change, vol. 3, no.3, pp. 557-605, 1994.

[18] B. Kogut, U. Zander, "Knowledge of the Firm, Combinative Capabilities, and the Replication of Technology," Organization Science, vol. 3, no.3, pp. 383-397, 1992.

[19] G. Szulanski, "Exploring internal stickiness: Impediments to the transfer of best practice within the firm," Strategic Management Journal, vol. 17, no.S2, pp. 27-43, 1996.

[20] U. Zander, B. Kogut, "Knowledge and the Speed of the Transfer and Imitation of Organizational Capabilities: An Empirical Test," Organization Science, vol. 6, no.1, pp. 76-92, 1995.

[21] D. J. Teece, G. Pisano, A. Shuen, "Dynamic capabilities and strategic management," Strategic Management Journal, vol. 18, no.7, pp. 509533, 1997.

[22] R. Nelson, S. Winter, An Evolutionary Theory of Economic Change, Cambridge MA: Belknap Harvard, 1982.

[23] M. E. Porter, "Towards a dynamic theory of strategy," Strategic Management Journal, vol. 12, no.S2, pp. 95-117, 1991.

[24] P. Ghemawat, B. Cassiman, "Introduction to the Special Issue on Strategic Dynamics," Management Science, vol. 53, no.4, pp. 529-536, 2007.

[25] J. S. Bain, "Workable Competition in Oligopoly: Theoretical Considerations and Some Empirical Evidence," The American Economic Review, vol. 40, no.2, pp. 35-47, 1950.

[26] J. S. Bain, "Relation of Profit Rate to Industry Concentration: American Manufacturing, 1936-1940," The Quarterly Journal of Economics, vol. 65, no.3, pp. 293-324, 1951.

[27] J. S. Bain, "Economies of Scale, Concentration, and the Condition of Entry in Twenty Manufacturing Industries," The American Economic Review, vol. 44, no.1, pp. 15-39, 1954.

[28] G. J. Stigler, "A Theory of Oligopoly," Journal of Political Economy, vol. 72, no.1, pp. 44-61, 1964.

[29] H. Demsetz, "Industry Structure, Market Rivalry, and Public Policy," The Journal of Law \& Economics, vol. 16, no.1, pp. 1-9, 1973.

[30] R. H. Coase, "The Nature of the Firm," Economica, vol. 4, no.16, pp. 386-405, 1937.

[31] O. E. Williamson, Chapter 3 Transaction cost economics. Handbook of Industrial Organization, vol. 1, pp. 135-182, 1989.

[32] O. E. Williamson, "The Modern Corporation: Origins, Evolution, Attributes," Journal of Economic Literature, vol.19, no.4, pp. 1537$1568,1981$.

[33] O. E. Williamson, The Economic Institutions of Capitalism: Firms, Markets, Relational Contracting (SSRN Scholarly Paper No. ID 1496720). Rochester, NY: Social Science Research Network, 1985.

[34] D. J. Teece, "Economies of scope and the scope of the enterprise," Journal of Economic Behavior \& Organization, vol. 1, no.3, pp. 223247, 1980.

[35] D. J. Teece, "Profiting from technological innovation: Implications for integration, collaboration, licensing and public policy," Research Policy, vol. 15, no.6, pp. 285-305, 1986.

[36] R. Jacobson, "The 'Austrian' School of Strategy," ACAD MANAGE REV , vol. 17, no. 4, pp. 782-807, Oct. 1992.

[37] R. M. Cyert, J. G. March, Behavioral Theory of the Firm (2 edition). Cambridge, Mass., USA: Wiley-Blackwell, 1992.

[38] H. A. Simon, Administrative Behavior. New York: Macmillan, 1957.

[39] K. R. Andrews, The concept of corporate strategy. New York: Dow Jones-Irwin, 1971.

[40] I. Ansoff, Corporate strategy. New York: McCraw-Hill, 1965.

[41] J.S. Bain, Industrial orgnization (2nd ed.). New York: Wiley, 1968.
[42] Scherer, F.M. industrial market structure and economic performance. Chicago: Rand McNally, 1970.

[43] T. C. Schelling, The strategy of conflict. Cambridge, Mass, 1960.

[44] J. Von Neumann, O. Morgenstern, Theory of Games and Economic Behavior: 3d Ed. Princeton University Press, 1953.

[45] M. E. Porter, "The contributions of industrial organization to strategic management," Academy of management review, vol. 6, no.4, pp. 609$620,1981$.

[46] F. W. Gluck, S. P. Kaufman, A. S. Walleck, "Strategic management for competitive advantage," Harvard Business Review. vol. 58, no.4, pp. 154-161, 1980.

[47] J. A. Schumpeter, The theory oi economic development. Cambridge, MA: Harvard University Press, 1934.

[48] J. A. Schumpeter, Capitalism, socialism and democracy. New York: Harpers, 1942.

[49] R. Nelson, "Goldschimd, Mann, and Weston's industrial concentration: The new learning," Bell Journal of Economics, vol. 7, pp. 729-732, 1976.

[50] M. T. Hannan, J. Freeman, "The Population Ecology of Organizations," American Journal of Sociology, vol. 82, no.5, pp. 929-964, 1977.

[51] R. R. Nelson, "Why do firms differ, and how does it matter?," Strategic management journal, vol. 12, no.S2, pp. 61-74, 1991.

[52] J. S. Bain, "Barriers to new competition," Cambridge, MA: Harvard University Press, Vol. 3, p. 55, 1956.

[53] G. Hamel, C. K. Prahalad, "To Revitalize Corporate Performance, We Need a Whole New Model of Strategy," Strategic intent, Harvard Business Review, vol. 67, no.3, pp. 63-76, 1989.

[54] J. McGee, H. Thomas, "Strategic groups: Theory, research and taxonomy," Strategic Management Journal, vol. 7, no.2, pp. 141-160, 1986.

[55] P. Ghemawat, Games Businesses Play: Cases and Models, New York NY: Wiley, 1995.

[56] A. M. Brandenburger, B. J. Nalebuff, Co-Opetition (1 edition). New York: Currency Doubleday, 1997.

[57] G. J. Mailath, L. Samuelson, Repeated Games and Reputations: LongRun Relationships, Oxford: Oxford University Press, 2006.

[58] A. M. Knott, "Persistent Heterogeneity and Sustainable Innovation," Strategic Management Journal, vol. 24, pp. 687-705, 2003.

[59] J. Barney, "Firm Resources and Sustained Competitive Advantage," Journal of Management, vol. 17, no.1, pp. 99-120, 1991.

[60] K. M. Eisenhardt, J. A. Martin, "Dynamic Capabilities: What Are They?," Strategic Management Journal, vol. 21, no.10/11, pp. 1105$1121,2000$.

[61] S. A. Lippman, R. P. Rumelt, "Uncertain Imitability: An Analysis of Interfirm Differences in Efficiency under Competition," The Bell Journal of Economics, vol. 13, no.2, pp. 418-438, 1982.

[62] R. P. Rumelt, Towards a strategic theory of the firm. In Lamb, R.B. (Ed.), Competitive Strategic Management. Englewood Cliffs, N.J.: Prentice-Hall, 1984.

[63] K. R. Conner, "A Historical Comparison of Resource-Based Theory and Five Schools of Thought Within Industrial Organization Economics: Do We Have a New Theory of the Firm?," Journal of Management, vol. 17, no.1, pp. 121-154, 1991.

[64] B. Wernerfelt, C. A. Montgomery, 'Tobin's q and the importance of focus in firm performance," American Economic Review, vol. 78, pp. 246-250, 1988.

[65] R. P. Rumelt, "Theory, strategy and entrepreneurship. In D. Teece (ed.)," The Competitive challenge, Cambridge: Ballinger, pp. 137-58, 1987.

[66] R. E. Caves, M. Porter, "From entry barriers to mobility barriers: Conjectural decisions and contrived deterrence to new competition," Quarterly Journal of Economics, vol. 91, pp. 241-262, 1977.

[67] P. Ghemawat, "Sustainable advantage," Harvard Business Review, pp. 53-58, Sept-Oct 1986.

[68] B. Wernerfelt, "From critical resources to corporate strategy," Journal of General Management, vol. 14, pp. 4-12, 1989.

[69] G. Dosi, R. R. Nelson, S. G. Winter, The Nature and Dynamics of Organizational Capabilities, Oxford: Oxford University Press, 2000.

[70] R. Makadok, "Toward a Synthesis of the Resource-Based and Dynamic-Capability Views of Rent Creation," Strategic Management Journal, vol. 22, pp. 387-401, 2001.

[71] S. G. Winter, "Understanding dynamic capabilities," Strategic Management Journal, vol. 24, no.10, pp. 991-995, 2003. 
[72] R. A. D'aveni, Hypercompetition (1 edition). New York: Toronto : New York: Free Press, 1994.

[73] R. A. D'Aveni, "Coping with hypercompetition: Utilizing the new 7S's framework," The Academy of Management Executive, vol. 9, no.3, pp. 45-57, 1995.

[74] L. J. Bourgeois, K. M. Eisenhardt, "Strategic Decision Processes in High Velocity Environments: Four Cases in the Microcomputer Industry," Management Science, vol. 34, no.7, pp. 816-835, 1998.

[75] S. L. Brown, K. M. Eisenhardt, Competing on the Edge: Strategy as Structured Chaos (1St Edition edition). Boston, Mass: Harvard Business Review Press, 1998

[76] J. W. Rivkin, "Imitation of Complex Strategies," Management Science, vol. 46, no.6, pp. 824-44, 2000.

[77] L. Mises, Human action: A treatise on economics. New Haven, CT: Yale University Press, 1949.

[78] R. Jacobson, "The Austrian School of Strategy," Academy of Management Review, vol. 17, no.4, pp. 782-807, 1992.

[79] G. Young, K. G. Smith, C. M. Grimm, "Austrian and Industrial Organization Perspectives on Firm-level Competitive Activity and Performance," Organization Science, vol. 7, no.3, pp. 243-254, 1996.

[80] M. J. Chen, "Competitive dynamics research: An insider's odyssey," Asia Pacific Journal of Management, vol. 26, no.1, pp. 5-25, 2009.

[81] R. A. D'Aveni, G. B. Dagnino, K. G. Smith, "The age of temporary advantage," Strategic Management Journal, vol. 31, no.13, pp. 1371$1385,2010$.

[82] J. A. C. Baum, H. J. Korn, "Competitive Dynamics Of Interfirm Rivalry," Academy of Management Journal, vol. 39, no.2, pp. 255291, 1996.

[83] K. G. Smith, C. M. Grimm, M. J. Gannon, Dynamics of competitive strategy. Newbury Park, CA: Sage Publications, 1992.

[84] D. J. Ketchen, C. C. Snow, V. L. Hoover, "Research on Competitive Dynamics: Recent Accomplishments and Future Challenges," Journal of Management, vol. 30, no.6, pp. 779-804, 2004.

[85] K. G. Smith, W. J. Ferrier, H. Ndofor, Competitive dynamics research: Critique and future directions. In The Blackwell Handbook of Strategic Management, Blackwell Publishers Ltd, pp. 314-361, 2001.

[86] I. C. MacMillan, M. L. McCaffery, G. Van Wijk, "Competitor's responses to easily imitated new products: Exploring commercial banking product introductions," Strategic Management Journal, vol. 6, pp. $75-86,1985$

[87] R. A. Bettis, D. Weeks, "Financial returns and strategic interaction: The case of instant photography," Strategic Management Journal, vol. 8, no.6, pp. 549-563, 1987.

[88] M. J. Chen, D. Miller, "Competitive Dynamics: Themes, Trends, and a Prospective Research Platform," The Academy of Management Annals, vol. 6, no.1, pp. 135-210, 2012.

[89] D. Sirmon, S. Gove, M. Hitt, "Resource management in dyadic competitive rivalry: The effects of resource bundling and deployment," Academy of Management Journal, vol. 51, pp. 919-935, 2008.

[90] H. A. Ndofor, D. G. Sirmon, X. He, "Firm resources, competitive actions and performance: Investigating a mediated model with evidence from the in-vitro diagnostics industry," Strategic Management Journal, vol. 32, pp. 640-657, 2011.
[91] W. Tsai, K. H. Su, M. J. Chen, Seeing through the eyes of a rival: Competitor acumen based on rival-centric perceptions. Academy of Management Journal, forthcoming, 2011.

[92] D. Miller, C. Droge, "Psychological and traditional predictors of organization structure," Administrative Science Quarterly, vol. 31, pp. 539-560, 1986.

[93] A. C. Hax, D. L. Wilde, The Delta Model -- Toward a Unified Framework of Strategy (SSRN Scholarly Paper No. ID 344580). Rochester, NY: Social Science Research Network, 2002.

[94] J. B. Rosser, "On the complexities of complex economic dynamics," The Journal of Economic Perspectives, vol. 13, pp. 169-192, 1999.

[95] W. B. Arthur, Complexity and the Economy (1 edition). Oxford; New York: Oxford University Press, 2014

[96] E. D. Beinhocker, The origin of wealth: Evolution, complexity, and the radical remaking of economics. Cambridge, MA: Harvard Business School Press, 2006.

[97] J. M. Epstein, Generative social science: Studies in agent-based computational modeling. New York: Princeton University Press, 2006.

[98] J. H. Miller, S.E. Page, Complex adaptive systems: An introduction to computational models of social life. New York: Princeton University Press, 2006.

[99] A. P. Kirman, Complex economics: Individual and collective rationality. The Graz Schumpeter Lectures, Routledge, 2011.

[100] D. G. Saari, "Mathematical complexity of simple economics," Notices of the American Mathematical Society, vol. 42, pp. 222-230, 1995.

[101] T. C. Schelling, Micromotives and macrobehaviour. New York: W. W. Norton, 1978.

[102] J. Crutchfield, "Is anything ever new? Considering emergence. In G. Cowan, D. Pines, \& D. Meltzer (Eds.)," Complexity: Metaphors, models, and reality, Reading, MA: Addison-Wesley, pp. 515-537, 1994.

[103] H. A. Simon, The sciences of the artificial. Cambridge, MA: MIT Press, 1969

[104] G. Dosi, G. Fagiolo, A. Roventini, "Schumpeter meeting Keynes: A policy- friendly model of endogenous growth and business cycles," Journal of Economic Dynamics \& Control, vol. 34, no.9, 1748-1767, 2010

[105] M. Gallegati, D. Delli Gatti, E. Gaffeo, P. Cirillo, S. Desiderio, Macroeconomics from the bottom-up. Berlin: Springer, 2010.

[106] D. F. Batten, Discovering artificial economics. Boulder, CO: Westview Press, 2000.

[107] M. Wooldridge, An introduction to multiagent systems. Chichester: Wiley, 2002.

[108] N. Gilbert and K. G. Troitzsch, Simulation for the social scientist. Maidenhead: Open Univ. Press, 2011.

[109] G. Nicolis and C. Nicolis, "Foundations of Complex Systems Nonlinear Dynamics, Statistical Physics, Information and Prediction," 2007.

[110] N. Gilbert and P. Terna, "How to build and use agent-based models in social science," Mind \& Society, vol. 1, no. 1, pp. 57-72, 2000.

[111] B. Mckelvey, "Perspective-Quasi-Natural Organization Science," Organization Science, vol. 8, no. 4, pp. 351-380, 1997.

[112] B. Mckelvey, "Complexity Theory in Organization Science: Seizing the Promise or Becoming a Fad?," Emergence, vol. 1, no. 1, pp. 5-32, 1999. 